\title{
SINTESIS DAN UJI TOKSISITAS SENYAWA ANALOG KALKON TERSUBSTITUSI METOKSI
}

\author{
Rahma Dona*, Adel Zamri, Jasril \\ Bidang Kimia Organik, Jurusan Kimia, FMIPA, Unversitas Riau \\ Email : rdona1985@yahoo.com
}

\begin{abstract}
ABSTRAK
Kalkon merupakan salah satu senyawa metabolit sekunder golongan flavonoid yang terdapat pada beberapa jenis tumbuhan dalam jumlah yang relatif sedikit. Senyawa ini merupakan prekursor untuk biosintesis flavonoid dan isoflavonoid. Senyawa kalkon telah dilaporkan memiliki berbagai aktivitas biologis yang menarik seperti antimikrob, antitumor, antioksidan, antiinflamasi, antimalaria, dan antikanker. Aktivitas senyawa kalkon dipengaruhi oleh gugus $\alpha, \beta$-tak jenuh dan substituen yang terdapat pada cincin aromatiknya. Pada penelitian ini, tiga analog kalkon tersubstitusi mono-metoksi pada cincin A aromatik dan cincin B aromatiknya telah disintesis menggunakan metode iradiasi microwave dengan katalis $\mathrm{KOH}$ dan pelarut etanol. Struktur setiap produk dikarakterisasi dengan spektroskopi UV-Vis, FTIR, ${ }^{1} \mathrm{H}$ NMR, ${ }^{13} \mathrm{C}$ NMR, dan HRMS. Uji toksisitas dilakukan menggunakan metode Brine Shrimp Lethality Test (BSLT). Berdasarkan hasil uji BSLT, ketiga senyawa tersebut berpotensi sebagai senyawa antikanker dengan nilai $\mathrm{LC}_{50}<200 \mu \mathrm{g} / \mathrm{mL}$.
\end{abstract}

Kata kunci: kalkon, uji toksisitas, Brine Shrimp Lethality Test (BSLT)

\section{PENDAHULUAN}

Kanker merupakan penyebab kematian kedua terbesar di dunia setelah penyakit jantung (Safavi et al., 2012). Berbagai macam senyawa telah dikembangkan untuk mengatasi kanker, akan tetapi tidak satupun jenis senyawa-senyawa tersebut menghasilkan efek yang memuaskan dan tanpa efek samping yang merugikan. Obat antikanker yang telah ada selain memiliki khasiat sebagai antikanker juga dapat merusak sel-sel normal. Oleh karena itu, hingga saat ini penelitian yang berhubungan dengan penemuan obat antikanker baru yang ampuh, aman dan selektif masih terus dilakukan oleh para peneliti.

Kalkon merupakan senyawa metabolit sekunder golongan flavonoid yang dapat ditemukan pada beberapa jenis tumbuhan. Senyawa kalkon dan turunannya dikenal memiliki beragam aktivitas biologis yang menarik, seperti antiviral, anti-inflamasi, antimikroba, antitumor, sitotoksik, analgesik, antijamur, antioksidan, antikanker dan antimalaria (Sarda et al, 2009). Koketsu et al. (2010), berhasil mensintesis senyawa 1,3-bis (4-klorofenil) - 3 -fenilsulfonil) propan-1-on yang berpotensi sebagai antibakteri. Selain itu, Yan-Fang et al. (2012), telah berhasil mengisolasi senyawa 3-hidroksi-4metoksilonkorkarpin yang berkhasiat sebagai antitumor dari tumbuhan Millettia pachycarpa.

Senyawa kalkon merupakan prekursor untuk biosintesis flavonoid dan isoflavonoid. Dalam bidang sintesis, senyawa kalkon telah banyak digunakan untuk membuat berbagai macam senyawa heterosiklik (Tiwari et al., 2010) seperti isoksazol, quinolinon, tiadiazin, benzodiazepin, flavon (Jayapal et al., 2010), ketimin $\alpha, \beta$ tak jenuh (Lonkar et al., 2011), pirazolin dan turunannya (Sharshira \& Hamada, 2011; Sing et al., 2009), flavonol (Britton et al., 2012; Jadhav et al., 2008), flavanonol (Patil, 2012) flavanon (Kulkarni, 2012) dan senyawa turunan lainnya yang juga memiliki aktivitas biologis yang menarik. Oleh karena itu, senyawa-senyawa analog kalkon dan turunannya banyak dijadikan sebagai molekul target untuk keperluan pencarian senyawa-senyawa aktif sebagai kandidat obat, salah satunya adalah sebagai obat antikanker.

Aktivitas biologis kalkon, selain disebabkan oleh gugus karbonil $\alpha, \beta$ tak jenuh, juga dipengaruhi oleh subtituen yang terikat pada kedua cincin aromatik (Kamble et al., 2011). Oleh karena itu, variasi subtituen pada cincin 
aromatik akan menghasilkan kalkon dengan struktur aktivitas yang beragam.

Pada umumnya, sintesis senyawa kalkon dilakukan melalui reaksi kondensasi Claisen Schmidt menggunakan turunan benzaldehid dan asetofenon. Reaksi pembentukan senyawa kalkon dapat dipercepat dengan penambahan katalis asam atau basa. Sintesis dapat dilakukan dengan metode pengadukan, pemanasan, refluks, dan iradiasi microwave. Namun beberapa tahun terakhir ini penggunaan energi microwave dalam reaksi organik sangat populer karena lebih aman, ramah lingkungan (green chemistry), cepat dan menghasilkan produk yang lebih banyak dibandingkan metode konvensional.

Senyawa hasil sintesis dikarakterisasi berdasarkan interpretasi data spektroskopi UVVis, FTIR, ${ }^{1} \mathrm{H}$ NMR, ${ }^{13} \mathrm{C}$ NMR, dan HRMS kemudian diuji sifat toksiknya dengan metode Brine Shrimp Lethality Test (BSLT). Uji BSLT merupakan salah satu teknik pendahuluan untuk menentukan letalitas atau toksisitas suatu senyawa. Uji ini merupakan uji pendahuluan untuk menentukan aktivitas antikanker dari suatu senyawa. Hal ini didasarkan pada pemikiran bahwa sebagian besar senyawa antikanker adalah bersifat toksik. Pengujian letalitas sederhana ini tidak spesifik untuk antikanker, tetapi merupakan indikator sitotoksik yang baik (Meyer et al., 1982). Berdasarkan metode BSLT, suatu tanaman atau hasil isolasi dianggap menunjukkan aktivitas sitotoksik bila mempunyai nilai $\mathrm{LC}_{50}$ kecil dari 1000 ppm, sedangkan untuk senyawa murni dianggap menunjukkan aktivitas sitotoksik bila mempunyai nilai $\mathrm{LC}_{50}$ kecil dari 200 ppm (Anderson et al., 1991).

\section{METODOLOGI PENELITIAN}

\section{Bahan dan Peralatan}

Bahan-bahan yang digunakan dalam penelitian ini adalah 2'-metoksi asetofenon (Merck), 3'-metoksi asetofenon (Merck), 4'metoksi asetofenon (Merck), -metoksibenzaldehid (Merck), 3-metoksibenzaldehid (Merck), 4metoksibenzaldehid (Merck), etanol (Merck), dimetilsulfoksida (Merck), kalium hidroksida (Merck), asam klorida $1 \mathrm{~N}$, telur udang (Artemia salina Leach), air laut dan pelarut-pelarut organik yang umum digunakan.

Alat-alat yang digunakan dalam penelitian ini adalah alat pengukur titik leleh (Fisher John), HPLC (Shimadzu LCsolution, jenis kolom ShimPack VP-ODS dengan panjang dan diameternya 150 x 4,6 mm), spektrofotometer UV-Vis (Genesys 10S UV-V VIS v4.002 2L9N175013), spektrofotometer FTIR (Shimadzu, IR Prestige21), spektroskopi ${ }^{1} \mathrm{H}$ NMR dan ${ }^{13} \mathrm{C}$ NMR (Agilent $500 \mathrm{MHz})$ di Institut Teknologi Bandung, spektroskopi massa (MS water LCT premier XE positive mode) di Institut Teknologi Bandung, alat-alat untuk sintesis dan uji toksisitas yang umum digunakan di laboratorium.

\section{Prosedur Kerja Sintesis}

Turunan asetofenon $(5 \mathrm{mmol})$ dan turunan benzaldehid $(5 \mathrm{mmol})$ dilarutkan dalam $5 \mathrm{~mL}$ etanol dan ditambahkan $15 \mathrm{mmol} \mathrm{KOH}$. Kemudian campuran diiradiasi menggunakan microwave dengan daya 180 Watt selama 8-15 menit. Tahapan reaksi diamati dengan KLT. Setelah proses reaksi selesai, campuran ditambahkan asam klorida $1 \mathrm{~N}$ dan akuades dingin hingga $\mathrm{pH}$ menjadi netral yang ditentukan dengan $\mathrm{pH}$ indikator. Endapan yang dihasilkan selanjutnya disaring dengan corong Buchner, dicuci dengan $n$-heksana dan akuades dingin, kemudian divakum hingga kering. Senyawa kalkon yang tidak murni direkristalisasi menggunakan etilasetat panas. Analisis kemurnian dilakukan melalui KLT, uji titik leleh, dan HPLC.

\section{Uji Toksisitas dengan Metode Brine Shrimp Lethality Test (BSLT)}

Uji toksisitas dengan metode BSLT dilakukan berdasarkan metode yang telah dilakukan oleh Meyer et al. (1982). Kista udang A. salina ditetaskan dalam wadah pembiakan yang berisi air laut, dan digunakan setelah aerasi selama 48 jam (setelah terbentuk larva). Vial uji dikalibrasi dengan $5 \mathrm{~mL}$ aquades. Uji aktivitas toksisitas senyawa analog kalkon dilakukan pada konsentrasi 10, 1 dan $0,1 \mu \mathrm{g} / \mathrm{mL}$. Sampel sebanyak $20 \mathrm{mg}$ dilarutkan dalam $2 \mathrm{~mL}$ metanol (larutan induk konsentrasi $1000 \mu \mathrm{g} / \mathrm{mL}$ ), 
kemudian dari larutan induk dibuat larutan dengan konsentrasi berbeda yaitu $10 \mu \mathrm{g} / \mathrm{mL}, 1$ $\mu \mathrm{g} / \mathrm{mL}$, dan $0,1 \mu \mathrm{g} / \mathrm{mL}$ dengan cara pengenceran bertingkat. Disiapkan vial yang sudah dikalibrasi $5 \mathrm{~mL}$ untuk masing-masing konsentrasi. Sampel dipipet ke dalam masing-masing vial, lalu diuapkan hingga mengering. Selanjutnya, kedalam masing-masing vial ditambahkan $50 \mu \mathrm{L}$ DMSO dan sedikit air laut. Sebanyak 10 ekor larva udang yang sudah disiapkan dimasukkan kedalam vial tersebut dan ditambahkan air laut hingga batas kalibrasi $5 \mathrm{~mL}$. Tingkat toksisitas senyawa analog kalkon diukur dengan cara menghitung jumlah larva udang yang mati dalam selang waktu 24 jam. Pengujian dilakukan dengan 3 kali pengulangan dan data dianalisis untuk menentukan nilai $\mathrm{LC}_{50}$ dengan metode kurva menggunakan tabel analisis probit.

\section{HASIL DAN PEMBAHASAN}

Senyawa analog kalkon $\left(\mathrm{RD}_{1}\right)-\left(\mathrm{RD}_{3}\right)$ diperoleh melalui reaksi kondensasi keton aromatik dan aldehid aromatik tersubstitusi mono-metoksi. Proses sintesis dipercepat dengan penambahan larutan $\mathrm{KOH}_{3} \mathrm{~N}$ sebagai katalis dibawah kondisi iradiasi microwave dengan daya
180 Watt selama 8-15 menit. Skema reaksi sintesis senyawa analog kalkon $\left(R_{1}\right)-\left(R_{3}\right)$ tersebut dapat dilihat pada Gambar 7.

Senyawa analog kalkon $\left(\mathrm{RD}_{1}\right)-\left(\mathrm{RD}_{3}\right)$ hasil sintesis berupa serbuk berwarna kuning. Rendemen senyawa murni yang dihasilkan cukup baik (51-63\%). Analisis kemurnian senyawa analog kalkon hasil sintesis ditentukan melalui KLT, titik leleh, dan HPLC. Analisis kemurnian dengan KLT dilakukan menggunakan eluen $n$ heksana: etil asetat (7:3) dan menunjukkan satu noda. Hasil analisis kemurnian dengan titik leleh diketahui bahwa jarak leleh senyawa analog kalkon secara teori dan hasil penelitian $\leq 2{ }^{\circ} \mathrm{C}$. Analisis kemurnian dengan HPLC menghasilkan kromatogram dengan satu puncak dominan pada $t_{R}=10,8$ menit untuk senyawa $(1), t_{R}=11,2$ menit untuk senyawa (2), dan $t_{R}=10,6$ menit untuk senyawa (3). Data tersebut menunjukkan bahwa senyawa analog kalkon $\left(\mathrm{RD}_{1}\right)-\left(\mathrm{RD}_{3}\right)$ yang dihasilkan telah murni. Senyawa analog kalkon $\left(\mathrm{RD}_{1}\right)-\left(\mathrm{RD}_{3}\right)$ dikarakterirasi menggunakan spektroskopi UV, IR, ${ }^{1} \mathrm{H}-\mathrm{NMR}$ dan HRMS. Sifat Fisik senyawa $\left(\mathrm{RD}_{1}\right)-\left(\mathrm{RD}_{3}\right)$ dapat dilihat pada Tabel 2.<smiles>[R][Y]1C=CC=C(C(=O)/C=C/C2=CC=C=[R]([R])=C2)C=C1</smiles>

$$
\begin{aligned}
& \left(\mathrm{RD}_{1}\right) \mathrm{R}=4-\mathrm{OMe}, \mathrm{R}^{\prime}=2-\mathrm{OMe} \\
& \left(\mathrm{RD}_{2}\right) \mathrm{R}=4-\mathrm{OMe}, \mathrm{R}^{\prime}=3-\mathrm{OMe} \\
& \left(\mathrm{RD}_{4}\right) \mathrm{R}=4-\mathrm{OMe}, \mathrm{R}^{\prime}=2-\mathrm{OMe}
\end{aligned}
$$

Gambar. 7. Reaksi sintesis senyawa analog kalkon $R_{1}-R_{3}$

Tabel. 2. Sifat fisik senyawa analog kalkon $\mathrm{RD}_{1}-\mathrm{RD}_{3}$

\begin{tabular}{ccccccc}
\hline Senyawa & $\begin{array}{c}\text { Rumus } \\
\text { Molekul }\end{array}$ & $\begin{array}{c}\text { Berat } \\
\text { Molekul }\end{array}$ & $\begin{array}{c}\text { Rendemen } \\
(\%)\end{array}$ & Warna & $\begin{array}{c}\text { Titik leleh } \\
\left({ }^{\circ} \mathrm{C}\right)\end{array}$ & $\begin{array}{c}\mathrm{R}_{\mathrm{f}} \\
(\text { n-heksan:EtOAc) }\end{array}$ \\
\hline$(1)$ & $\mathrm{C}_{17} \mathrm{H}_{16} \mathrm{O}_{3}$ & 269,1173 & 51,14 & Kuning & $96-98$ & $0,78(7: 3)$ \\
$(2)$ & $\mathrm{C}_{17} \mathrm{H}_{16} \mathrm{O}_{3}$ & 269,1180 & 62,07 & Kuning & $46-48$ & $0,82(7: 3)$ \\
$(3)$ & $\mathrm{C}_{17} \mathrm{H}_{16} \mathrm{O}_{3}$ & 269,1176 & 63,91 & Kuning & $62-64$ & $0,74(7: 3)$ \\
\hline
\end{tabular}


Spektrum UV senyawa $\mathrm{RD}_{1}-\mathrm{RD}_{3}$ dalam pelarut metanol $(\mathrm{MeOH})$ berturut-turut memperlihatkan adanya serapan maksimum pada $\lambda 205 \mathrm{~nm}, 236 \mathrm{~nm}$, dan $346 \mathrm{~nm}$ untuk senyawa (1), serapan maksimum pada $\lambda 207$ $\mathrm{nm}, 223 \mathrm{~nm}$, dan $343 \mathrm{~nm}$ untuk senyawa (2), serapan maksimum pada $\lambda 206 \mathrm{~nm}, 221 \mathrm{~nm}$, dan $334 \mathrm{~nm}$ untuk senyawa (3) menunjukkan adanya ikatan rangkap terkonjugasi yang merupakan ciri khas dari senyawa kalkon.

Spektrum FTIR senyawa $\mathrm{RD}_{1}-\mathrm{RD}_{3}$ memperlihatkan adanya serapan pada bilangan gelombang $\left(\mathrm{cm}^{-1}\right)$ 1660-1667 mengindikasikan adanya gugus $\mathrm{C}=\mathrm{O}$ terkonjugasi dengan ikatan rangkap $\alpha, \beta$ tak jenuh. Serapan pada bilangan gelombang 1564-1606 mengindikasikan adanya ikatan $\mathrm{C}=\mathrm{C}$ alkena yang terkonjugasi dengan karbonil dan cincin aromatik. Serapan pada bilangan gelombang 3070-3080 mengindikasikan adanya ikatan $\mathrm{C}-\mathrm{H}$ aromatik. Serapan pada bilangan gelombang 1166-1178 mengindikasikan adanya ikatan C-OMe.

Spektrum ${ }^{1} \mathrm{H}-\mathrm{NMR}$ senyawa analog kalkon $\mathrm{RD}_{1}-\mathrm{RD}_{9}$ menunjukkan pergeseran yang khas pada proton gugus metoksi. Proton tersebut terdapat pada pergeseran kimia $\delta 3,00$ 4,00 ppm dengan puncak singlet dan integritas $3 \mathrm{H}$. Proton yang terdapat pada $\mathrm{C}_{\alpha}$ dan $\mathrm{C}_{\beta}$ memiliki nilai tetapan kopling $(J)$ 15-16 Hz dengan puncak doublet. Nilai tetapan kopling tersebut menunjukkan bahwa ikatan rangkap pada $\mathrm{C}_{\alpha}$ dan $\mathrm{C}_{\beta}$ mempunyai konfigurasi trans.

Tabel. 3. Interpretasi data ${ }^{1} \mathrm{H}$ NMR senyawa analog kalkon $\mathrm{RD}_{1}, \mathrm{RD}_{2}$, dan $\mathrm{RD}_{3}$

\begin{tabular}{|c|c|c|c|}
\hline \multirow{2}{*}{$\begin{array}{c}\text { Nomor } \\
\text { Atom }\end{array}$} & Senyawa $\mathrm{RD}_{1}$ & Senyawa $\mathrm{RD}_{2}$ & Senyawa $\mathrm{RD}_{3}$ \\
\hline & $\delta_{\mathrm{H}}(\mathrm{ppm})$ & $\delta_{\mathrm{H}}(\mathrm{ppm})$ & $\delta_{\mathrm{H}}(\mathrm{ppm})$ \\
\hline 1 & - & - & - \\
\hline 2 & $7,60(\mathrm{~d} ; 2 \mathrm{H} ; J=8,5 \mathrm{~Hz})$ & $7,60(\mathrm{~d} ; 2 \mathrm{H} ; J=8,5 \mathrm{~Hz})$ & $7,53(\mathrm{~d} ; 2 \mathrm{H} ; J=8,5 \mathrm{~Hz})$ \\
\hline 3 & $6,94(\mathrm{~d} ; 2 \mathrm{H} ; J=9 \mathrm{~Hz})$ & $6,93(\mathrm{~d} ; 2 \mathrm{H} ; J=9 \mathrm{~Hz})$ & $6,91(\mathrm{~d} ; 2 \mathrm{H} ; J=9 \mathrm{~Hz})$ \\
\hline 4 & $3,85\left(\mathrm{~s}, 3 \mathrm{H},-\mathrm{OCH}_{3}\right)$ & $3,85\left(\mathrm{~s}, 3 \mathrm{H},-\mathrm{OCH}_{3}\right)$ & $3,84\left(\mathrm{~s}, 3 \mathrm{H},-\mathrm{OCH}_{3}\right)$ \\
\hline \multirow{2}{*}{$\begin{array}{l}\text { Nomor } \\
\text { Atom }\end{array}$} & Senyawa RD1 & Senyawa RD2 & Senyawa RD3 \\
\hline & $\delta \mathrm{H}(\mathrm{ppm})$ & $\delta \mathrm{H}(\mathrm{ppm})$ & $\delta \mathrm{H}(\mathrm{ppm})$ \\
\hline 5 & $6,94(\mathrm{~d} ; 2 \mathrm{H} ; J=9 \mathrm{~Hz})$ & $6,93(\mathrm{~d} ; 2 \mathrm{H} ; J=9 \mathrm{~Hz})$ & $6,91(\mathrm{~d} ; 2 \mathrm{H} ; J=9 \mathrm{~Hz})$ \\
\hline 6 & $7,60(\mathrm{~d} ; 2 \mathrm{H} ; J=8,5 \mathrm{~Hz})$ & $7,60(\mathrm{~d} ; 2 \mathrm{H} ; J=8,5 \mathrm{~Hz})$ & $7,53(\mathrm{~d} ; 2 \mathrm{H} ; J=8,5 \mathrm{~Hz})$ \\
\hline $\mathrm{C} \alpha$ & $7,43\left(\mathrm{~d} ; 1 \mathrm{H}_{\alpha} ; J=15,5 \mathrm{~Hz}\right)$ & $7,39\left(\mathrm{~d} ; 1 \mathrm{H}_{\alpha} ; J=15,5 \mathrm{~Hz}\right)$ & $7,23\left(\mathrm{~d} ; 1 \mathrm{H}_{\alpha} ; J=16 \mathrm{~Hz}\right)$ \\
\hline $\mathrm{C} \beta$ & $7,78\left(\mathrm{~d} ; 1 \mathrm{H}_{\beta} ; J=15,5 \mathrm{~Hz}\right)$ & $7,78\left(\mathrm{~d} ; 1 \mathrm{H}_{\beta} ; J=16 \mathrm{~Hz}\right)$ & $7,54\left(\mathrm{~d} ; 1 \mathrm{H}_{\beta} ; J=15,5 \mathrm{~Hz}\right)$ \\
\hline 1 ' & - & - & - \\
\hline 2 ' & $8,03(\mathrm{~d} ; 2 \mathrm{H} ; J=8,5 \mathrm{H})$ & 7,53 (t; 1H; $J=2 \mathrm{~Hz})$ & $3,89\left(\mathrm{~s}, 3 \mathrm{H},-\mathrm{OCH}_{3}\right)$ \\
\hline 3 ' & $6,98(\mathrm{~d} ; 2 \mathrm{H} ; J=9 \mathrm{~Hz})$ & $3,88\left(\mathrm{~s}, 3 \mathrm{H},-\mathrm{OCH}_{3}\right)$ & $6,99(\mathrm{~d} ; 2 \mathrm{H} ; J=8,5 \mathrm{~Hz})$ \\
\hline 4 ' & $3,89\left(\mathrm{~s}, 3 \mathrm{H},-\mathrm{OCH}_{3}\right)$ & $\begin{array}{c}7,11\left(\mathrm{dd} ; 1 \mathrm{H} ; J_{a}=2,5 \mathrm{~Hz} \text { dan }\right. \\
\left.J_{b}=10,5 \mathrm{~Hz}\right)\end{array}$ & $7,46(\mathrm{t} ; 1 \mathrm{H}, J=7,5 \mathrm{~Hz})$ \\
\hline 5 & $6,98(\mathrm{~d} ; 2 \mathrm{H} ; J=9 \mathrm{~Hz})$ & $7,40(\mathrm{t} ; 1 \mathrm{H} ; J=8 \mathrm{~Hz})$ & 7,03 (d; 1H; $J=7,5 \mathrm{~Hz})$ \\
\hline $6^{\prime}$ & $8,03(\mathrm{~d} ; 2 \mathrm{H} ; J=8,5 \mathrm{H})$ & $7,59(\mathrm{~d} ; 1 \mathrm{H} ; J=6 \mathrm{~Hz})$ & $\begin{array}{c}7,59\left(\mathrm{dd} ; 1 \mathrm{H} ; J_{\mathrm{a}}=3 \mathrm{~Hz} \text { dan }\right. \\
\left.J_{\mathrm{b}}=4,5 \mathrm{~Hz}\right)\end{array}$ \\
\hline
\end{tabular}


Berat molekul senyawa-senyawa hasil sintesis dikonfirmasi melalui spektroskopi massa (HRMS). Berat molekul senyawa $\mathrm{RD}_{1}$ ditunjukkan oleh spektrum massa yang dihitung sebagai $\mathrm{C}_{17} \mathrm{H}_{16} \mathrm{O}_{3}[\mathrm{M}+\mathrm{H}]^{+}$dengan puncak ion molekul m/z 269,1178 dan ditemukan pada spektrum massa dengan puncak ion molekul $\mathrm{m} / \mathrm{z}$ 269,1173 , selisih massa molekul tersebut 0,0005 . Berat molekul senyawa $\mathrm{RD}_{2}$ ditunjukkan oleh spektrum massa yang dihitung sebagai $\mathrm{C}_{17} \mathrm{H}_{16} \mathrm{O}_{3}$ $[\mathrm{M}+\mathrm{H}]^{+}$dengan puncak ion molekul $\mathrm{m} / \mathrm{z}$ 269,1178 dan ditemukan pada spektrum massa dengan puncak ion molekul $\mathrm{m} / \mathrm{z} 269,1180$, selisih massa molekul tersebut 0,0002 . Berat molekul senyawa $\mathrm{RD}_{3}$ ditunjukkan oleh spektrum massa yang dihitung sebagai $\mathrm{C}_{17} \mathrm{H}_{16} \mathrm{O}_{3}[\mathrm{M}+\mathrm{H}]^{+}$dengan puncak ion molekul m/z 269,1178 dan ditemukan pada spektrum massa dengan puncak ion molekul $\mathrm{m} / \mathrm{z}$ 269,1176, selisih massa molekul tersebut 0,0002.. Selisih massa berdasarkan spektrum massa dengan massa perhitungan menunjukkan perbedaan yang sangat kecil antara senyawa yang diharapkan dengan senyawa kalkon yang diperoleh dan dapat dikatakan bahwa senyawa kalkon tersebut sangat murni. Dengan demikian dapat dikatakan bahwa senyawa kalkon tersebut mempunyai struktur sesuai dengan yang diharapkan .

Uji toksisitas terhadap senyawa kalkon $\mathrm{RD}_{1}-\mathrm{RD}_{3}$ dilakukan menggunakan metode BSLT. Hasil uji toksisitas terhadap senyawa kalkon tersebut dapat dilihat pada Tabel 4.

Tabel. 4. Hasil uji toksisitas

\begin{tabular}{cc}
\hline Senyawa & Nilai $\mathbf{L C}_{\mathbf{5 0}}(\boldsymbol{\mu} \mathbf{g} / \mathbf{m L})$ \\
\hline $\mathrm{RD}_{1}$ & 1,045 \\
$\mathrm{RD}_{2}$ & 2,008 \\
$\mathrm{RD}_{3}$ & 0,617 \\
\hline
\end{tabular}

Berdasarkan uji BSLT yang telah dilakukan, dapat dikatakan bahwa senyawa-senyawa kalkon turunan 2'-hidroksiasetofenon tersebut berpotensi aktif sebagai senyawa antikanker yang dibuktikan dengan nilai $\mathrm{LC}_{50}<200 \mu \mathrm{g} / \mathrm{mL}$.

\section{KESIMPULAN DAN SARAN}

Melalui penelitian ini telah dihasilkan tiga analog kalkon tersubstitusi mono-metoksi dikedua cincin aromatik dengan rendemen yang cukup baik (51-63\%). Sintesis dilakukan melalui reaksi kondensasi Claisen-Schmidt menggunakan metode iradiasi microwave dengan katalis $\mathrm{KOH}$ dan menggunakan etanol sebagai pelarut. Hasil karakterisasi melalui spektroskopi UV-Vis, FTIR, ${ }^{1} \mathrm{H}$ NMR, ${ }^{13} \mathrm{C}$ NMR, dan HRMS menunjukkan bahwa ketiga senyawa hasil sintesis memiliki struktur sesuai dengan yang diharapkan. Berdasarkan hasil uji pendahuluan menggunakan metode BSLT dapat disimpulkan bahwa ketiga senyawa hasil sintesis berpotensi aktif sebagai senyawa antikanker yang dibuktikan dengan nilai $\mathrm{LC}_{50}<200 \mu \mathrm{g} / \mathrm{mL}$.

\section{DAFTAR PUSTAKA}

Anderson, J.E. Goetz, C.M., dan Mclaughlin, J.L. 1991. A Blind Comparison of Simple Bench Top Bioassay and Human Tumor Cell Cytotoxicity as Antitumor Prescreens. Pytochemical Analysis. 2(3): 107-111.

Britton, R.G., Horner-Glister, E., Pomenya, O.A., Smith, E.E., Denton, R., Jenkins, P.R., Steward, W.P., Brown, K., Gescher, A., dan Sale, S. 2012. Synthesis and Biological Evaluation of Novel Flavonols as Potential Anti-Prostate Cancer Agent. European Journal of Medicinal Chemistry. 54: $952-$ 958.

Jadhav, S.B., Bagul, K.R., Bagul, P.R., dan Gaikwad, K.V. 2008. Synthesis of Some Novel Flavonol Derivatives and Its Antimicrobial Activity. Oriental Journal of Chemistry. 24(2): 583-588.

Jayapal, M.R., Prasad, K.S., dan Sreedhar, N.Y. 2010. Synthesis and Characterization of 2,6-dihydroxy Substituted Chalcones Using PEG-400 as a Recyclable Solvent. J. Pharm. Sci \& Res. 2(8):450-458.

Kamble, V.M., Hatnapure, G.D., Keche, A.P., Birajdar, S., Patil, S.G., Tale, R.H., Rodge, A.H., Turkar, S.S., dan Gour, K. 2011. Sintesis and Biological Evaluation of a Novel Series of Methoxylated Chalcones as Antioxidant and Anti-microbial agents. $J$. Chem. Pharm. Res. 3(6):639-648.

Kulkarni, P., Wagh, P., dan Zubaidha, P. 2012. An Improved and Eco-Friendly Method for 
The Synthesis of Flavanone by The Cyclization of 2'-Hydroxy Chalcone using Methane Sulphonic Acid as Catalyst. Chemistry Journal. 2(3): 106-110.

Lonkar, S.M., Mokle, S.S., Vibhute, A.Y., dan Vibhute, Y.B. 2011. Green Approach for The Synthesis of Some New $\alpha, \beta$ Unsaturated Ketimines under Water Suspension. Orbital Elec. J. Chem. 3(4):197-203.

Meyer, B.N., Ferrigni, N.R., Putnam, J.E., Jacosen, L.B., Nichols D.E., dan McLaughin, J.L. 1982. Brine Shrimp: A Convenient General Bioassay for Active Plant Constituens. Journal of Medicinal Plant Research Planta Medica. 45: 31-34.

Patil, V.J. 2012. Synthesis and In Vitro Antiplaque Activity of Chalcone, Flavonol and Flavanol Derivatives. IJPSR. 3(12): 5006-5014.

Safavi, M., Esmati, N., Ardestani, S. K., Emami, S., Ajdari, S., Davoodi, J., Shafiee, B., \& Foroumadi, A. 2012. Halogenated flavanones as potensial apoptosis-including agent: Synthesis and biological activity evaluation. European Journal of Medicinal Chemistry. 58:573-580.

Sarda, S.R., Bhusare, S.R., Dake, S.A., Jadhav, W.N., dan Pawar, R.P. 2009. Solvent-free $\mathrm{NaOH}-\mathrm{Al} 2 \mathrm{O} 3$ supported synthesis of 1,3diaryl-2-propene-1-ones. International Journal of ChemTech Research. 1(2): 265269.

Sharshira, E.M. dan Hamada, N.M.M. 2011. Synthesis and In Vitro Antimicrobial Activity of Some Pyrazolyl-1-carboxamide Derivatives. Molecules. 16: 7736-7745.

Sing, P., Negi, J.S., Pant, G.J.N., Rawat, M.S.M. \& Budakoti, A. 2009. Synthesis and Characterization of a Novel 2-Pyrazoline. Molbank, 613: 1-4.

Tiwari, B., Pratapwar, A.S., Tapas, A.R., Butle, S.R., dan Vatkar, B.S. 2010. Synthesis and Antimicrobial Activity of some chalcone derivatives. International Journal of ChemTech Research. 2(1): 499-503.
Yang-Fang, L., Bing, L., Cong-Ying, L., XueHui, S., Yu-Jiao, Z., dan Zhi-Peng, Y. 2012. A new prenylated chalcone from the seeds of Millettia pachycarpa. Chinese Journal of Natural Medicines. 10(3): 222-225 dan Beberapa Kriteria Kualitas Sayuran Daun Spinasia, Universitas Padjajaran, Bandung.

I. Kohar, P. H. Hardjo, L. Wijaya, 2005. Jurnal Ilmiah Sains \& Teknologi I. Vol.2.

Rumajar, A.T.B. 2010. Skripsi "Penjajakan Kadar Logam Berat $\mathrm{Pb}$ Pada Tanaman Kangkung Darat (Ipomoea reptans Poir) Asal Kecamatan Medan Deli Dan Kangkung Air (Ipomoea aquatica Forsk) Asal Kecamatan Sunggal Kota Medan”, USU, Medan

Sunarjono. H, 2013, Bertanam 36 Jenis Sayur, Jakarta, Penebar Swadaya.

Suparwoko, 2008, Puring paling Top Serap Timbal, artikel majalah Trubus Online, http://www.trubus-

nline.co.id/mod.php?mod=publisher\&op

$=$ viewarticle $\&$ cid $=1 \&$ artid $=1414$ edisi Jumat, Agustus 2008, diakses Februari 2013.

Suharto, 2005, Dampak Pencemaran Logam Timbal (Pb) terhadap tubuh. Efek Toksik Logam. Yogyakarta.

Tafajani. H, 2011, Panduan Komplit Bertanam Sayur dan Buah-buahan, Yogyakarata, Cahaya Atma.

Widiningrum, Miskiyah dan Suismono, 2007, Jurnal pertanian. Ahaya Kontaminasi Logam Berat Dalam Sayuran dan Alternatif Pencegahan Cemarannya, Vol.3, Balai Besar Penelitian dan Pengembangan Pasca Panen Pertanian, Jakarta.

Widowati, 2008. Pencemaran Logam Berat Terhadap Sayuran. Jurnal Sains. Jakarta.

Widowati. H. 2011. Pengaruh Logam Berat Cd, $\mathrm{Pb}$ Terhadap Perubahan Warna Batang dan Daun Sayuran. Jurnal Sains. Vol. 1, No. 4. 